\title{
Pengaruh Pemberian Parental Kit Activity Book terhadap Kemampuan Adaptasi Anak pada Masa Pandemi Covid-19
}

\author{
Ely Rahmatika Nugrahani
}

Prodi D III Keperawatan, Fakultas Ilmu Kesehatan, Univesitas Muhammadiyah Jember Alamat Korespondensi: Gumuk Kerang, Karangrejo, Kec. Sumbersari, Kabupaten Jember, Jawa Timur - Indonesia 68124

Email: ely.rahmatika.n@gmail.com

Diterima: 29 April 2021 |Disetujui: 27 Juni 2021

\begin{abstract}
Abstrak
Latar Belakang dan Tujuan: Pandemi Covid-19 memaksa anak-anak untuk mampu menyesuaikan dengan kondisi saat ini. Anak-anak merupakan korban tersembunyi dari pandemi Covid-19 yang perlu mendapatkan perhatian khusus dari berbagai pihak. Adanya pandemi Covid-19 menyebabkan anak-anak memiliki kualitas tidur yang buruk, peningkatan adanya mimpi buruk, nafsu makan menurun, kurangnya perhatian, dan masalah psikologis. Penelitian ini bertujuan menganalisis pengaruh Parental Kit Activity Book terhadap kemampuan beradaptasi anak pada masa pandemi Covid-19.

Metode: Penelitian ini menggunakan one group pretest-posttes design pada siswa TK Nusa Indah Ambulu Jember. Sampel penelitian menggunakan total sampling sebanyak 25 responden. Pemilihan responden telah mendapatkan persetujuan dari orangtua wali responden serta didampingi guru kelas. Uji paired t-test didapatkan nilai $p$ value $0,000<0,05$.

Hasil: Hasil penelitian didapatkan peningkatan kemampuan adaptasi pada siswa dengan ditandai peningkatan mean pre-test dan post-test, serta peningkatan aspek self-knowledge, self-acceptance, self-control, dan self-satisfaction dari cukup menjadi baik. Usia responden dan sifat buku edutainment membuat anak lebih mudah menerima informasi yang diberikan, sehingga kemampuan adaptasi meningkat.

Simpulan dan Implikasi: Parental Kit Activity Book mampu meningkatkan kemampuan anak dalam mengatasi perubahan lingkungan untuk bertahan di masa pandemi Covid-19.
\end{abstract}

Kata Kunci: Adaptasi; Pandemi Covid-19; Parental Kit Activity Book

\footnotetext{
Sitasi: Nugrahani, E. R. (2021). Pengaruh pemberian parental kit activity book terhadap kemampuan adaptasi anak pada masa pandemi covid-19. The Indonesian Journal of Health Science. 13(1), 110-119. DOI: $10.32528 /$ ijhs.v13i1.5024

Copyright: (92021 Nugrahani, E. R. This is an open-access article distributed under the terms of the Creative Commons Attribution-NonCommercial 4.0 International License, which permits unrestricted use, distribution, and reproduction in any medium, provided the original author and source are credited.

Diterbitkan Oleh: Universitas Muhammadiyah Jember

ISSN (Print): 2087-5053

ISSN (Online): 2476-9614
} 


\begin{abstract}
Background and Aim: Covid-19 pandemic forces children to be able adapt to current situations. Children were hidden victims of the Covid-19 pandemic which need special attention. The Covid-19 pandemic causes children to have poor sleep quality, increased nightmares, decreased appetite, lack of attention, and psychological problems. The purpose of this study was to analysis the effect of the Parental Kit Activity Book on children's adaptation during the Covid-19 Pandemic.

Methods: The study used a one group pretest-posttest design on the students of TK Nusa Indah Ambulu Jember. The sample selection in this study used a total sampling of 25 respondents. The selection of respondents has received approval from the parents and accompanied by the teacher.

Results: The results of the paired t-test showed a p-value of $0.000<0.05$. The results of the study obtained an increase in students' adaptation ability by an increase in the mean pre-test and post-test results, increase in aspects of selfknowledge, self-acceptance, self-control, and self-satisfaction. Age and edutainment book make it easier for children to receive the information provided, so that their adaptability increases.
\end{abstract}

Conclusion: The Parental Kit Activity Book was able to improve children's adaptability during the Covid-19 Pandemic.

Keywords: Adaptation; Covid-19 Pandemic; Parental Kit Activity Book

\section{PENDAHULUAN}

Transmisi yang kuat dari manusia ke manusia akibat Coronavirus 2019 (Covid-19) masih menjadi masalah utama di seluruh dunia (Chen et al., 2020). Kematian yang semakin bertambah akibat Covid19 terus mengalami peningkatan (Titov et al., 2020). Pemutusan rantai penularan pada kelompok rentan merupakan tugas utama yang harus terus dilakukan dalam memerangi masalah tersebut (Chen et al., 2020).

Angka kejadian Covid-19 di dunia hingga 1 Desember 2020 mencapai 62.363.527 jiwa terkonfirmasi (World Health Organization, 2020). Asia Tenggara menduduki peringkat ke 4 dengan kasus terkonfirmasi sebanyak 686.192 jiwa (World Health Organization, 2020). Indonesia merupakan negara terdampak Covid-19 dan tercatat sebanyak 539.000 jiwa terkonfirmasi positif (Badan Nasional Penanggulangan Bencana, 2020). Jawa Timur menduduki peringkat kedua provinsi yang memiliki angka kasus tertinggi yaitu sebanyak 61.883 jiwa kasus dalam konfirmasi, $\quad 54.490$ sembuh, dan 4.407 jiwa meninggal dunia (Gugus Tugas Provinsi Jawa Timur, 2020). Jember sebagai salah satu kabupaten dengan zona merah, memiliki kasus terkonfirmasi sebanyak 2.441 jiwa, 1.796 sembuh, dan 111 meninggal dunia (Gugus Tugas Kabupaten Jember, 2020). Dengan demikian angka kejadian Covid-19 masih tinggi dan dimungkinkan akan terus bertambah jika tidak ada pencegahan secara komprehensif.

Covid-19 merupakan penyakit menular melalui droplet dengan masa inkubasi 1-14 hari yang disebabkan oleh Severe Acute Respiratory 
Syndrome Coronavirus 2 (SARS-CoV2) (Keliat et al., 2020). Paru-paru merupakan organ yang diserang melalui sel inang dengan mengubah Angiotensin Converting Enzyme 2 (ACE2). SARS-CoV-2 yang berikatan dengan ACE2 memasuki sel inang, lalu masuk kemudian menginfeksi tubuh.

$\begin{array}{ccc}\text { Langkah non farmasi } & \text { dapat } \\ \text { digunakan } & \text { sebagai } & \text { upaya }\end{array}$
mengendalikan wabah. Menggunakan masker, mencuci tangan, dan menjaga jarak tepat diterapkan ketika beraktivitas di luar rumah, sedangkan isolasi di rumah tepat digunakan untuk anak-anak sebagai langkah utama pencegahan penyebaran wabah Covid19 (Chen et al., 2020).

UNICEF mengatakan bahwa anak-anak merupakan korban tersembunyi pada masa pandemi Covid-19 (Muratori et al., 2020). Situasi pendemi mengharuskan anakanak menyesuaikan diri, di mana konsekuensi psikolgis harus mereka hadapi (Muratori et al., 2020). Hasil penelitian mengatakan bahwa selama masa pandemi anak-anak memiliki kualitas tidur yang buruk, peningkatan adanya mimpi buruk, nafsu makan menurun, ketidaknyamanan fisik, agitasi, dan kurangnya perhatian (Jiao et al., 2020). Peran orang tua dalam hal ini dituntut untuk lebih ekstra membantu meningkatkan ketahanan diri pada anak selama masa pandemi, dengan demikian anak mampu beradaptasi dengan baik.

Orang tua dapat mendukung psikologis anak selama pandemi dengan cara memahami bagaimana menangani kondisi darurat kesehatan psikologis (Muratori et al., 2020). Anak berhak mendapatkan informasi tentang situasi pandemi sesuai dengan usia dan bahasa yang mudah dipahami. Anak-anak cenderung tidak mampu mengekspresikan emosi mereka dibandingkan dengan orang dewasa, sehingga manifestasi yang dimunculkan seperti ketakutan mendadak, kekhawatiran, serta gangguan tidur sering terjadi (Muratori et al., 2020). Hasil penelitian mengatakan bahwa komunikasi melalui gambar, cerita, bermain, dan aktivitas lain dapat menjadi media orang tua dalam meningkatkan resiliensi anak (Muratori et al., 2020).

Hasil studi pendahuluan di TK Nusa Indah Ambulu didapatkan bahwa dari 10 siswa didapatkan 6 anak belum mengetahui Covid-19. Hasil wawancara didapatkan bahwa mereka mengatakan ingin bermain dengan teman-teman seperti biasanya. Anak mengatakan bahwa belum pernah mendapatkan pendidikan kesehatan tentang Covid-19. Dengan demikian dapat disimpulkan bahwa siswa TK Nusa Indah Ambulu perlu mendapatkan terapi khusus untuk meningkatkan kemampuan beradaptasi selama masa pandemi.

Resiliensi pada anak mampu meningkatkan kemampuan individu dalam beradaptasi terhadap situasi yang sulit (McCubbin \& McCubbin, 1996). Salah satu terapi resiliensi pada anak dapat menggunakan Parental Kit Activity Book. Hasil penelitian didapatkan bahwa buku merupakan media yang dapat meningkatkan resiliensi pada anak melalui kegiatan bermain (Tatlow-golden et al., 2015). Activity book dapat meningkatkan interaksi antara orangtua dan anak, sehingga selain dapat meningkatkan ketahanan dan adaptasi psikologis, juga dapat sebagai media komunikasi keduanya serta menstimulus perkembangan anak (Laforett \& Mendez, 2016).

Muhammadiyah merupakan lembaga pendidikan yang memiliki 
prinsip pembaharuan (Tajdid) untuk terus berkemajuan (Ișlah) (Mardani, 2015). Prinsip tersebut mendorong peneliti untuk merespon persoalan yang terjadi di masyarakat khususnya generasi Muhammadiyah di TK Nusa Indah Ambulu sebagai upaya pencegahan dan membantu masyarakat dalam menjalani masa pandemi dengan meningkatkan ketahanan psikologis di Kabupaten Jember. Keterkaitan penelitian ini adalah sebagai perwujudan prinsip Kemuhammadiyahan dan Catur Dharma Perguruan Tinggi dalam bidang pendidikan.

Hasil penelitian sebelumnya oleh Aditya Pradana et al. (2021) mengatakan bahwa pendidikan kesehatan melalui lagu mampu meningkatkan kemampuan anak dalam beradaptasi, dalam hal ini ditunjukkan dengan kemampuan anak melakukan pencegahan Covid-19 dengan CTPS (Cuci Tangan Pakai Sabun). Hasil penelitian sebelumnya oleh Jaji (2020) mengatakan bahwa pendidikan kesehatan melalui leaflet mampu meningkatkan kemampuan individu dalam melakukan pencegahan Covid19 sebagai upaya adaptasi terhadap perubahan akibat pandemi. Penelitian sebelumnya belum ada yang melakukan upaya pencegahan Covid19 melalui pemberian Parental Kit Activity Book, sehingga peneliti tertarik untuk mengetahui pengaruh pemberian Parental Kit Activity Book terhadap kemampuan adaptasi anak pada masa pandemi Covid-19 Di TK Nusa Indah Ambulu.

\section{METODE PENELITIAN}

Desain
menggunakan eksperimental dengan
rancangan penelitian one group
pretest-posttest design.
rancangan penelitian dipilih karena

ingin mengetahui pengaruh pemberian intervensi dan membandingkan sebelum dan sesudah perlakukan yakni Parental Kit Activity Book terhadap kemampuan adaptasi anak pada Masa Pandemi Covid-19 Di TK Nusa Indah Ambulu.

Populasi penelitian ini adalah siswa TK Nusa Indah Ambulu, sedangkan sampel siswa TK Nusa Indah Ambulu yang memenuhi kriteria inklusi dan eksklusi. Kriteria inklusi pada penelitian ini adalah 1) siswa TK Nusa Indah Ambulu, 2) usia anak 4-5 tahun, 3) wali mengijinkan untuk dijadikan responden. Kriteria ekslusi pada penelitian ini adalah 1) menolak menjadi responden, 2) dalam kondisi sakit dan tidak masuk sekolah.

Teknik sampling yang digunakan adalah total sampling, yaitu semua siswa yang memenuhi kriteria inklusi berhak menjadi responden penelitian. Jumlah sampel pada penelitian ini adalah 25 siswa.

Penilaian pada penelitian ini menggunakan metode observasi dengan mengacu pada konsep adaptasi menurut Alberlt \& Emmons (2002). Observasi terdiri dari empat aspek yaitu self-knowledge, self-acceptance, self-control, dan self-satisfaction. Observasi dilakukan oleh petugas khusus yang membantu peneliti dalam mengambil data, yaitu dua orang yang sebelumnya telah dilakukan penyamaan persepsi.

\section{HASIL PENELITIAN}

Hasil distribusi karakteristik responden pada tabel 1 didapatkan bahwa mayoritasi responden berusia 14 tahun yaitu 11 siswa (56\%), dan berjenis kelamin laki-laki yaitu 17 siswa (68\%). Hal tersebut menunjukkan bahwa siswa lebih mampu memiliki kemampuan dalam menerima informasi yang diberikan. 
Tabel 1. Distribusi Karakteristik Distribusi Responden

\begin{tabular}{lcc}
\hline \multicolumn{1}{c}{ Kategori } & n & \% \\
\hline Usia & & \\
a. 4 tahun & 11 & 44 \\
b. 5 tahun & 14 & 56 \\
\hline Total & $\mathbf{2 5}$ & $\mathbf{1 0 0}$ \\
\hline Jenis Kelamin & & 68 \\
a. Laki-laki & 17 & 32 \\
b. Perempuan & 8 & $\mathbf{1 0 0}$ \\
\hline Total & $\mathbf{2 5}$ & \\
\hline
\end{tabular}

Tabel 2. Distribusi Karakteristik Distribusi Responden

\begin{tabular}{lcccc}
\hline \multicolumn{1}{r}{ Aspek } & \multicolumn{2}{c}{ Pre } & \multicolumn{2}{c}{ Post } \\
\cline { 2 - 5 } Self-Knowledge & $\mathbf{n}$ & $\mathbf{\%}$ & $\mathbf{n}$ & $\mathbf{\%}$ \\
a. Baik & 0 & 0 & 21 & 84 \\
b. Cukup & 16 & 64 & 4 & 16 \\
c. Kurang & 9 & 36 & 0 & 0 \\
\hline Total & $\mathbf{2 5}$ & $\mathbf{1 0 0}$ & $\mathbf{2 5}$ & $\mathbf{1 0 0}$ \\
\hline Self-acceptance & & & 23 & 92 \\
a. Baik & 4 & 16 & 2 & 8 \\
b. Cukup & 21 & 84 & 0 & 0 \\
c. Kurang & 0 & 0 & $\mathbf{2 5}$ & $\mathbf{1 0 0}$ \\
\hline Total & $\mathbf{2 5}$ & $\mathbf{1 0 0}$ & 22 & 88 \\
\hline Self-control & & & 3 & 12 \\
a. Baik & 0 & 0 & 0 & 0 \\
b. Cukup & 20 & 80 & $\mathbf{2 5}$ & $\mathbf{1 0 0}$ \\
c. Kurang & 5 & 20 & & \\
\hline Total & $\mathbf{2 5}$ & $\mathbf{1 0 0}$ & 23 & 92 \\
\hline Self-satisfaction & & & 2 & 8 \\
a. Baik & 0 & 0 & 0 & 0 \\
b. Cukup & 20 & 80 & $\mathbf{2 5}$ & $\mathbf{1 0 0}$ \\
c. Kurang & 5 & 20 &
\end{tabular}

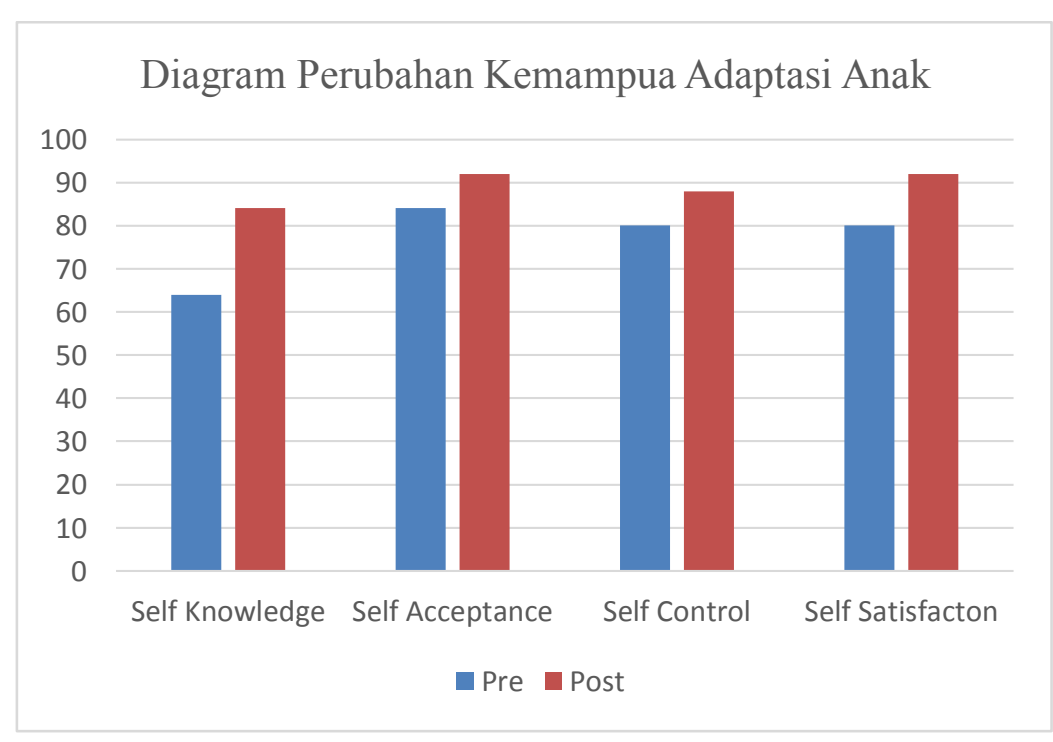

Diagram 1. Perubahan Kemampuan Adaptasi Anak 
Tabel 3. Distribusi Karakteristik Distribusi Responden

\begin{tabular}{lccc}
\hline \multicolumn{1}{c}{ Kategori } & Mean & $\begin{array}{c}\text { Standar } \\
\text { Deviasi }\end{array}$ & p-value \\
\hline Pre test & 7,72 & 0,092 & 0,000 \\
\hline Post test & 11,80 & 0,082 & 0,000 \\
\hline
\end{tabular}

Distribusi variabel penelitian pada tabel 2 diketahui bahwa mayoritas siswa mengalami peningkatan self-knowledge, selfacceptance, self-control, dan selfsatisfaction. Hal tersebut menunjukkan bahwa siswa memiliki kemampuan adaptasi yang baik terhadap pandemi Covid-19. Kemampuan adaptasi tersebut mengalami peningkatan sebelum dan sesudah pemberian Parental Kit Activity Book.

Hasil analisis pada tabel 3 diperoleh nilai $p$-value $0,000<0,05$ dengan demikian terdapat pengaruh Parental Kit Activity Book terhadap kemampuan adaptasi anak pada Masa Pandemi Covid-19 Di TK Nusa Indah Ambulu. Hasil penelitian juga terdapat peningkatan pre dan post pemberian Parental Kit Activity Book. Hal tersebut menunjukkan bahwa Parental Kit Activity Book mampu meningkatkan kemampuan adaptasi siswa, sehingga siswa memiliki kemampuan dalam menyesuaikan diri terhadap perubahan aktivitas, pencegahan Covid-19, serta mempertahankan kesehatan selama masa pandemi.

\section{PEMBAHASAN}

Kemampuan adaptasi pada penelitian ini adalah suatu kemampuan penyesuaian diri terhadap perubahan akibat adanya pandemi Covid-19. Kemampuan adaptasi dibangun oleh self-knowladge, self-acceptance, selfcontrol, dan self-satisfaction. Kemampuan adaptasi bertujuan untuk menghadapi tuntutan perubahan lingkungan, mengadapi tuntutan keadaan secara objektif dan rasional (Gerungan, 2006). Pada penelitian ini hasil akhir yang diharapkan adalah siswa mampu melakukan adaptasi terhadap perubahan pada masa pandemi.

Hasil penelitian sebelumnya didapatkan bahwa kemampuan adaptasi dapat meningkatkan imunitas individu dalam mengadapi pandemi Covid-19 (Haryadi et al., 2020). Siswa diharapkan mampu beradaptasi pada perubahan lingkungan akibat pandemi Covid-19. Kemampuan beraptasi akan meningkatkan imunitas individu dengan menekan sitokin pro-inflamasi sehingga kejadian Covid-19 dapat dicegah. Individu yang mampu beradaptasi akan cenderung memiliki tingkat stress yang rendah, sehingga produksi sitokin menurun (Rosyanti et al., 2017). Dengan demikian kejadian Covid-19 dapat dicegah.

Hasil penelitian didapatkan bahwa siswa TK Nusa Indah Ambulu Jember memiliki self-knowlade yang baik. Sebelum dilakukan pemberian Parental Kit Activity Book mayoritas siswa memiliki self-knowladge cukup. Setelah dilakukan pemberian Parental Kit Activity Book siswa mengalami peningkatan menjadi baik. Pada Parental Kit Activity Book siswa diajak melakukan refleksi tentang konsep Covid-19, mulai dari pengertian, cara pencegahan, dan cara peningkatan imunitas untuk mencegah terjadinya Covid-19. Hasil penelitian sebelumnya didapatkan bahwa self-knowledge mampu meningkatkan adaptasi 
individu pada masa pandemi Covid-19 (Nisa, 2020). Dengan demikian selfknowledge mampu meningkatkan kemampuan adaptasi siswa pada masa pandemi Covid-19. Self-knoewledge mampu peningkatan komitmen di dalam diri individu untuk merubah perilaku adaptif termasuk dalam mencegah Covid-19 dengan melakukan protokol kesehatan.

Hasil penelitian didapatkan bahwa siswa TK Nusa Indah Ambulu Jember memiliki self-acceptance yang baik. Sebelum dilakukan pemberian Parental Kit Activity Book mayoritas siswa memiliki self-accetance cukup. Setelah dilakukan pemberian Parental Kit Activity Book siswa mengalami peningkatan menjadi baik. Pada Parental Kit Activity Book siswa diajak melakukan refleksi tentang perubahan apa saja yang terjadi sebelum dan saat pandemi Covid-19 terjadi. Hasil penelitian sebelumnya mengatakan bahwa self-acceptance berhubungan positif terhadap kemampuan adaptasi individu (Dewi, 2020). Dengan demikian dapat disimpulkan bahwa self-acceptance mampu mempengaruhi adaptasi siswa. Semakin tinggi selfacceptance siswa terhadap kondisi pandemi Covid-19, maka akan semakin tinggi pula adaptasi siswa terhadap perubahan tersebut. Selfacceptance juga dapat meningkatkan kepercayaan diri siswa untuk menghadapi perubahan lingkungan, karena siswa akan merasa menadap dukungan dari orang lain.

Hasil penelitian didapatkan bahwa siswa TK Nusa Indah Ambulu Jember memiliki self-control yang baik. Sebelum dilakukan pemberian Parental Kit Activity Book mayoritas siswa memiliki self-control cukup. Setelah dilakukan pemberian Parental Kit Activity Book siswa mengalami peningkatan menjadi baik. Pada
Parental Kit Activity Book siswa diajarkan cara mencegah Covid-19, yaitu melakukan cuci tangan dengan sabun dan air mengalir, memakai masker, serta cara batuk dan bersin yang baik. Hasil penelitian sebelumnya didapatkan bahwa self-control berhubungan signifikan dengan kemampuan adaptasi individu (Eliza, 2019). Dengan demikian dapat disimpulkan bahwa self-control mampu meningkatkan adaptasi siswa pada masa pandemi. Self-control mampu untuk menyusun, mengatur, dan mengarahkan perilaku ke arah positif. Self-control juga meningkatkan kemampuan inidvidu dalam memodifikasi perilaku, memilih perilaku dan tindakan sesuai dengan yang diyakini, dalam hal ini adalah pencegahan Covid-19.

Hasil penelitian didapatkan bahwa siswa TK Nusa Indah Ambulu Jember memiliki self-satisfaction yang baik. Sebelum dilakukan pemberian Parental Kit Activity Book mayoritas siswa memiliki self-satisfaction cukup. Setelah dilakukan pemberian Parental Kit Activity Book siswa mengalami peningkatan menjadi baik. Pada Parental Kit Activity Book siswa diajak melakukan refleksi terkait akibat atau dampak apa saja yang akan dialami apabila tidak melakukan pencegahan Covid-19. Hasil penelitian sebelumnya didapatkan bahwa self-satisfaction dapat meningkatkan kemampuan individu dalam melakukan penyesuaian diri (Kumalasari et al., 2012). Dengan demikian dapat disimpulkan bahwa self-satisfaction mampu meningkatkan adaptasi siswa pada masa pandemi. Self-satisfaction didapat dari pengalaman individu dalam hal ini adalah refleksi dampak jika tidak melakukan pencegahan Covid-19, dengan demikian siswa akan merasa puas karena mendapatkan 
alasan mengapa ia harus melakukannya. Dengan adanya kepuasan pada diri siswa tersebut akan meningkatkan kemampuan siswa dalam bertahan pada kondisi yang tidak menyenangkan yakni pandemi Covid-19.

Pemberian Parental Kit Activity Book dilakukan pada anak dengan mengacu pada dimensi penunjang yaitu self-knowladge, self-acceptance, self-control, dan self-satisfaction. Parental Kit Activity Book diberikan di sekolah dan diisi dengan dipandu oleh peneliti, serta didampingi oleh guru kelas. Siswa diminta berdiskusi, baik sebelum pemberian, selama pemberian, serta diakhir sesi sebagai evaluasi.

Hasil penelitian sebelumnya didapatkan bahwa terdapat hubungan antara fun book learning dengan peningkatan perkembangan anak usia dini (Isnaini, 2019). Anak mudah memahami informasi yang diberikan melalui buku yang menyenangkan dan menarik, sehingga anak dapat bermain sambil belajar. Buku yang menyenangkan juga akan merangsang anak lebih kreatif dalam menerima informasi melalui kegiatan yang menyenangkan seperti mewarnai, mencocokkan, menggunting dan menempel, dan kegiatan lain yang menyenangkan. Parental Kit Activity Book merupakan media pembelajaran yang menyenangkan bagi anak, dengan demikian dapat disimpulkan bahwa Parental Kit Activity Book dapat meningkatkan pemahaman informasi khususnya kemampuan dalam melakukan adaptasi anak pada masa pandemi Covid-19.

Activity book merupakan media pembelajaran yang bersifat edutainment dan dalam bentuk yang interaktif, sehingga merangsang rasa ingin tahu anak (Hikariza \& Sihombing, 2015). Anak diajak untuk terjun langsung pada situasi tertentu, dalam hal ini adalah terkait Covid-19, dengan demikian anak akan lebih mudah mendapatkan pengalaman informasi.

Keberhasilan pemberian Parental Kit Activity Book juga dapat dipengaruhi oleh usia anak. Hasil penelitian didapatkan bahwa mayoritas anak berusia 5 tahun yaitu sebanyak 14 siswa (56\%). Usia anak mempengaruhi kemampuan dalam menerima informasi. Hal tersebut didukung oleh hasil penelitian Kiki, Candrawati and Putri (2018) bahwa usia mempengaruhi tingkat pengetahuan siswa terhadap pendidikan kesehatan yang telah diberikan. Usia seseorang mempengaruhi daya tangkap dan pola pikir seseorang, semakin bertambah usia seseorang maka daya tangkap dan pola pikir akan berkembang sesuai dengan usianya, sehingga individu memperoleh penegtahuan semakin baik (Suwaryo \& Yuwono, 2017). Semakin tua usia individu akan lebih mudah menerima informasi yang didukung oleh peningkatkan struktur otak dan pengalaman yang diterima.

\section{SIMPULAN}

Parental Kit Activity Book berpengaruh terhadap kemampuan adaptasi anak TK Nusa Indah Ambulu yang ditunjukkan oleh adanya perubahan mean pre dan post intervensi. Keberhasilan pemberian Parental Kit Activity Book dipengaruhi oleh usia responden, dan sifat buku edutainment sehingga anak mudah menerima informasi yang diberikan.

\section{SARAN}

Peneliti belum bisa melibatkan orangtua pada penelitian khususnya yang berkaitan dengan pengisian Parental Kit Activity Book. Saran bagi peneliti selanjutnya untuk melibatkan 
orangtua, karena salah satu faktor keberhasilan adaptasi adalah pola asuh orangtua.

Peneliti belum bisa melihat keberhasilan Parental Kit Activity Book secara berkala sampai dengan siswa menunjukkan perubahan perilaku. Saran bagi peneliti selanjutnya untuk melihat perubahan kemampuan adaptasi pada level psikomotor, yakni sampai siswa melakukan perubahan perilaku secara nyata sehingga adaptasi yang diperoleh benar-benar nyata.

\section{DAFTAR PUSTAKA}

Aditya Pradana, K., Peristiowati, Y., Dian Ellina, A., Widiyanto, A., \& Tri Atmojo, J. (2021). Pengaruh Pendidikan kesehatan animasi lagu anak-anak terhadap pengetahuan cuci tangan pakai sabun (CTPS) anak usia sekolah pada masa pandemi covid-19 di Desa Gembol Ngawi. Avicenna: Journal of Health Research, 4(1), 24-33.

https://doi.org/10.36419/avicenna. v4i1.456

Badan Nasional Penanggulangan Bencana. (2020). Gugus tugas percepatan penanganan covid-19 Republik Indonesia.

Chen, X., Ran, L., Liu, Q., Hu, Q., Du, X., \& Tan, X. (2020). Hand hygiene, mask-wearing behaviors and its associated factors during the covid-19 epidemic: A crosssectional study among primary school students in Wuhan, China.

Dewi, R. R. S. (2020). Hubungan antara adaptasi diri dengan self acceptance ibu dalam merawat anak stunting.

Eliza, S. (2019). Hubungan kontrol diri dengan penyesuaian diri pada siswa kelas viii di SMP
Adhyaksa Kota Jambi. https://repository.unja.ac.id/id/epr int $/ 9490 \% 0 \mathrm{~A}$

Gugus Tugas Kabupaten Jember. (2020). Data covid-19.

Gugus Tugas Provinsi Jawa Timur. (2020). Jatim tanggap covid-19.

Haryadi, A. Y., Dewi, A. N., Pradana, D., Ricardo, J., Salsabilah, M., Syahputra, M. A., Faustina, P. A., Putri, N. E., Nadia, T., \& Fiorentina, T. (2020). Upaya edukasi untuk beradaptasi pada kebijakan new normal dan meningkatkan imunitas tubuh selama pandemi covid-19 melalui kegiatan seminar online education for new normal adaptation and improving body immunity during covid-19 pandemic through online semin. 4(2), 441-447.

Hikariza, A. J., \& Sihombing, R. M. (2015). Activity book pengenalan pemanfaatan pekarangan untuk anak-anak. 1, 9.

Isnaini, I. D. (2019). Pengaruh fun book learning terhadap perkembangan anak. Buah Hati, $6(2)$.

Jaji. (2020). Pengaruh pendidikan kesehatan dengan media leaflet terhadap pengetahuan warga dalam pencegahan penularan covid 19. Proceeding Seminar Nasional Keperawatan 2020, 1, 135-139.

http://conference.unsri.ac.id/index .php/SNK/article/view/1764

Jiao, W. Y., Wang, L. N., Liu, J., Fang, S. F., Jiao, F. Y., PettoelloMantovani, M., \& Somekh, E. (2020). Behavioral and emotional disorders in children during the covid-19 epidemic. January.

Keliat, B. A., Marliana, T., Windarwati, H. D., Mubin, M. F., Sodikin, M. A., Kristianingsih, T., 
Prawiro, A., Trihadi, D., \& Kembaren, L. (2020). Dukungan kesehatan jiwa dan psikososial covid-19: Keperawatan jiwa. Fakultas Keperawatan Universitas Indonesia.

Kiki, F., Candrawati, E., \& Putri, R. M. (2018). Pengaruh pendidikan kesehatan terhadap peningkatan pengetahuan dalam pemilihan jajan pada anak usia sekolah 7-9 tahun Desa Ngantru Kecamatan Ngantang Kabupaten Malang. Journal Nursing News, XI(1), 3137.

Kumalasari, F., Pengajar, S., \& Psikologi, F. (2012). Hubungan antara dukungan sosial dengan penyesuaian diri remaja di Panti Asuhan Latifah Nur Ahyani. 1(1).

Laforett, D. R., \& Mendez, J. L. (2016). Play beliefs and responsive parenting among lowincome mothers of preschoolers in the United States. 4430(June). https://doi.org/10.1080/03004430. 2016.1169180

Mardani. (2015). Peran studi kemuhammadiyahan dalam keberterimaan ideologi muhammadiyah pada mahasiswa di Universitas Muhammadiyah Surakarta.

Muratori, P., Maris, I. S., \& Tirreno, V. (2020). Perspective article Children and the COVID-19 transition: Psychological reflections and suggestions on adapting to the emergency Pietro Muratori, Rebecca Ciacchini. 131-134.
Nisa, D. F. (2020). Sosialisasi menuju penerapan adaptasi kebiasaan baru pada santri pondok pesantren di Kabupaten Lumajang. Journal of Chemical Information and Modeling, 4(9), 8.

Rosyanti, L., Devianti, R., Hadi, I., \& Syahrianti, S. (2017). Hubungan antara depresi dengan sistem neuroimun (Sitokin-HPA Aksis). Health Information: Jurnal Penelitian, 9(2), 35-52.

Suwaryo, P. A. W., \& Yuwono, P. (2017). Faktor-faktor yang mempengaruhi tingkat pengetahuan masyarakat dalam mitigasi bencana alam tanah longsor. Urecol 6th, 305-314.

Tatlow-golden, M., Farrelly, C. O., Booth, A., Rourke, C. O., \& Doyle, O. (2015). ' Look, I have my ears open ': Resilience and early school experiences among children in an economically deprived suburban area in Ireland. https://doi.org/10.1177/01430343 15613777

Titov, N., Staples, L., Kayrouz, R., Cross, S., Ryan, K., Dear, B., \& Nielssen, O. (2020). Rapid report: Early demand, profiles and concerns of mental health users during the coronavirus (COVID19) pandemic. Internet Interventions, 100327. https://doi.org/10.1016/j.invent.20 20.100327

World Health Organization. (2020). WHO coronavirus disease (COVID-19) Dashboard. 